\title{
Urban Environment Renovation: A Shift in Professional Focus
}

\author{
Irina Kukina, ${ }^{1, *}$

\begin{abstract}
${ }^{1}$ Scientific Research Institute of the Theory and History of Architecture and Urban Planning Branch of the Central Scientific-Research and Project Institute of the Construction Ministry of Russia, Siberian Federal

*Corresponding author. Email: ikukina@inbox.ru
\end{abstract} \\ University, Krasnoyarsk, Russia
}

\begin{abstract}
The article analyzes the research of the "post-socialist city" in domestic science and foreign authors, in Russian and the countries of Eastern Europe in connection with large-scale renovation. Renovation in the Russian cities is carried out on residential areas of the 1960-1980s panel housing constructions, that is up to $30 \%$ of the housing stock of cities, associated with the doctrine of a socialist city (sotsgorod). Changes in the requirements for the modern environment of the city, guidelines for professional activity in this regard are investigated. The results of the study of modern methods of urban renovation are resented. This process is assumed to be a product of renovation, reconstruction, restoration without destroying the integrity of the urban structure. It was concluded that the urban integrity should be considered regarding the development trends, existing in the residential areas, the accumulation of qualities and processes occurring simultaneously and non-simultaneously. There is quite sophisticated comprehension of renovation strategies' aims, as well as firm and flexible elements of the city structure, and the design process components, such as methods, sequence, driving forces, and "efforts" of active participants.
\end{abstract}

Keywords: Renovation, Post-socialist city, Professional focus.

\section{INTRODUCTION}

In the last decade, the notion of "postsotsgorod" has entered the science as a guide for an effective renovation. Its nature is analyzed through the philosophy of "socialist city" and "social city" put on the modern lifestyle and cutting-edge technologies. The mid- $20^{\text {th }}$ century architecture becomes a focus, and, in its terms, there is a strong idea that building a "socialist city is an integral part of modernism. One also can see there how humanistic ideas about the living environment are evaluating from ordinary everyday needs to awakening of traditions and customs, uniqueness of settlements, respect for the community, as well as to being actively involved in forming the living environment. There are local autonomous

*Fund: This study is based on the research, supported by the Program of Fundamental Research of the Russian Academy of Architecture and Construction Sciences and of the Ministry of Construction, Housing and Utilities of the Russian Federation 2021. associations, and as for the foreign experience, a participatory planning is being of a great use.

In the end of the $20^{\text {th }}$ century, the changes in politics, economy, and technologies have led to large-scale conversions - the things that cause structural and architectural transformations of cities, re-orientation of the urban life and labor activity, as well as deviation of professional focuses in architectural creativity and urban planning. Thus, it becomes relevant to study a 50-years (and even more) life of the sotsgorod, alongside with its architectural heritage and ways of renovating the mass residential development.

\section{THEORETICAL FRAMEWORK}

As far as the renovation of residential areas goes, there is a few research sets carried out in sociology, landscape sciences, economics and environmental studies, architecture, and morphology. 
L.B. Kogan addresses the role of territory in social life and proposes integrating the functions and communication areas [1]. N.P. Krainyaia and I.V. Kukina define the essence and content of mobility and accessibility in spatial organization of residential development and consider the influence of socio-economic aspects of housing policy on its architectural and typological development [2, 3]. N.M. Trubnikova emphasizes that homogeneity of micro-districts is the result construction simplicity, low urban planning flexibility [4]. G.Z. Kaganov points out the fact of amorphous, hypertrophied residential buildings and similarity in mass housing [5]. K.V. Kiyanenko developed the methods of applied social investigation of the living environment [6]. I.G.Fedchenko proves that there are the residential units are based both on permanent and changeable components, for which there are specific criteria and parameters [7].

E.M. Mikulina, B.T. Tobilevich, V.I. Gutsalenko, and I. V. Kukina concern the landscape and environmental principles of residential areas modeling and forecasting, relying on the nature facilities [8]. The urban and environmental approach to the residential buildings reconstruction in the cities is grounded in the works of A.G. Bolshakov [9]. The social and environmental principles of the landscape worldview for residential building are determined by V.A. Nefedova, N.A. Unagaeva and others [10], [11]. L.V. Anisimova suggests that the type of interpersonal relationships, together with the sociopsychological parameters of the environment, can determine a living space model [12].

The architectural and urban planning heritage of socialistic construction, as well as adjustment of urban residential development to new socioeconomic conditions, and the methods of mass panel housing renovation in the post-Socialistic countries are revealed by K. Stanilov, I. Medvedkova, D. Smidt, B. Engel, M. Blanco, A. Kantarek, J. Samuels, R. Gold, M.M. Gold, M. Taylor, D. Kish et al [13], [14], [15], [16].

K.V. Kiyanenko, G.A. Ptichnikova, and E.V. Yeschina consider the ways of people's "participation" in planning and reconstruction of housing [17], [18], [19]. The mechanisms of autonomy for residential planning associations social and territorial entities - are studied by T.V. Filanova, while the socio-demographic "selforganization" of a 20th century foreign city's living environment is empirically and sociologically investigated in a big group of works [20].
The whole scientific data allow to formulate a methodology of the comprehensive analyzes on the "post-sotsgorod", and on the experience of architectural heritage renovation in that period. This also helps to conduct an in-field and remote examination of the renovated samples belonging to the 1960-1980 buildings construction, and to claim the shift in professional accents to a different conceptual field under the modern urban planning.

\section{DEVELOPING THE CONCEPT: FROM "SOCIALISTIC" TO "POST-SOCIALISTIC" CITY}

5th and 7th Congresses of the International Union of Architects, held in Moscow, 1958, and in Havana, 1963, respectively, and the United Nations International Symposium of Experts for New Cities Planning and Building, organized in Moscow, September 1964, agreed on the relevance of a micro-districts system-based urban planning structure. By the middle of the 20th century, this concept entered the USSR, the Comecon countries, and China (working unit). The close concepts of neighborhood and community have been widely used in the world since an earlier period.

Micro-districts are seen only through the spatial division of the city's main functions, i.e. everyday life, work, recreation, primary and secondary education, and pedestrian inter-realms. The structure welcomed educational institutions, health care facilities and trade organizations. The middle of $1970 \mathrm{~s}$ brought new views on the living environment, centered on differences in culture, on geographical, ethnographic, and national features. The researchers remain criticizing about the microdistricts minded urban planning. The main reason for that is the rigidity of functional zoning in the scheme of residential planning units, the stepwise service system; hypertrophied free spaces; unsolved landscape and environmental problems; gap between industrial methods of mass construction and the social order; aggressive appearance of housing; ban for residents on participating in planning and construction or to influence the results. The beginning of the 1980s brought the ideas of a "pedestrian-oriented", people-friendly living environment, full of multifunctionality and eco-friendliness for the residential construction. The idea of the systems of independent urban communication centers) was proposed. The functionalist model was replaced by the environmental one. In West Germany, in eastern cities, the planning policy cardinally changed from 
the state-backed to a "co-participation" of all those interested in renovating the panel housing construction; similar methods were gradually being applied in Hungary and Slovenia.

The increasing complexity of residential morphology emerges from the unplanned commercially active zone. There is a sharp tension in the problem of inter-connection between the areas of different purposes - open public spaces and small residential units. In the group of studies of factual changes in the morphology of microdistricts, for sample, I.G. Fedchenko proves the trend for their development pushed by the properties of constant (firm) and naturally changeable (flexible) elements [21]. The last of them includes residential housing of various archetypes, considered as primary social loci; a network of pre-school institutions and schools, interlinked by public spaces within safe pedestrian accessibility, is one of the main factors for the "social city" planning. As for the borders, the external ones are represented by the transport communication, and the natural environment fragments, while the internal boundaries, which enable protection and maintenance of private, public, and partially accessible territories, are formed mainly through the landscape architecture as the flexible elements are changing. The system of pedestrian paths and green zones should be hierarchically built from a personal (possibly) garden in the adjoining area to a garden (a park) in the residential planning unit and enter the green system of the city. Open public spaces are entrusted with the task of ensuring the accessibility of all functional zones and territories. The spatial hierarchy relied on the degree of privacy makes different activities and interaction available for the residents, thereby preventing social stratification and contributing to the public control development. Flexible space-planning elements, in turn, consists of commercially active public zone that forms pedestrian streets mainly with a built-in or/and attached service facilities; mixed forms of housing, and at-home entrepreneurship and freelance, and office spaces. The zone's functions are currently regulated merely by the tertiary sector, the total socialization of the first floors can reduce the courtyard spaces and their typical uses and require applied norms and regulations.

\section{THE FOREIGN EXPERIENCE IN RENOVATING THE RESIDENTIAL AREAS}

The foreign experience in renovating the microdistricts of the "sotsgorod" shows that they are considered as microeconomic objects. The commercially active zone forms business partnerships between businesses, companies, residents, and administrations. The system of taxation and the city budget, the expenditures of which are revealed to the residents (e.g. in the eastern cities of Germany) are being contributed.

Regarding the professional environment, there is a landscape and eco-friendly worldview, formed on a balanced and harmonious coexistence of anthropogenic and natural environments. It assumes that any ecosystem encompasses a unique area that should be preserved when designing a living environment. In West Germany, the renovation projects highlight the attempts to recreate a "sustainable landscape" by adapting to the local context, managing the impacts of economic reconstruction, and using ergonomic construction methods, especially in relation to open and "green" sites, water, energy, and waste. The project policy stays close to the applied research of the Berlin Technical University, under "LongLife" module, aimed at minimizing anthropogenic impacts on the human environment. In this case, the landscape of residential areas can be analyzed in three aspects spatial and anthropometric, planning, and psychological and behavioral.

The development of residential planning units as a social and administrative structural element of the city targets joining different social groups under one area. Thus, a hierarchy of autonomous institutions develops, creating a possibility for coordinating the life of many subjects and monitoring over very different processes and interests in the living environment.

\section{THE 1950-1970S TECHNOLOGICAL MODERNISM}

Recently, in the countries of Eastern Europe, a few discussions have been made concerning the possibility, methods, and strategies of renovating "socialist heritage" areas pursuing creation of a comfortable living environment. "The semantics of this verbal construction seems to be obvious: it is in many factors testifying to the high qualities of residential construction: 'all-inclusiveness', 'complexity', 'humanity'" [22]. K.V. Kiyanenko 
emphasizes the tolerance of environmental attitude, which can combine different components occurring simultaneously and indivisibly, making the consciousness to decide which fragment of reality can be integrated there" [23]. The living environment renovation can be planned in several ways, avoiding unambiguity, but in "adaptive planning", ... complicating the morphological structure; rethinking the essence and content of public spaces ..." [24]. Bernd Hunger notes that one must strive for the reconstruction of residential buildings, alongside with the social facilities and public spaces modernization, to provide a standard of living that would meet the majority's demands, not just of those with low incomes. In opposite to not quite popular and fueled by bad clichés of the media, micro-districts, in fact, have vast green areas and open spaces; local communities manage the adjacent territories, which can be used to create new formats of housing and commercial spaces, which allows solving the unemployment problem; most of the apartments are owned by the local housing companies and cooperatives, and the residents are, in most cases, tenants. These companies have economic and organizational advantages for the renovation of certain buildings and areas. It is much more difficult to carry out the same actions in areas with an extensive ownership structure. Bernd Hunger insists that residential renovation should be the rule, while its demolition - the exception. Zala Velkavrch argues that in Slovenia, "the construction of residential neighborhoods bound to industrial enterprises with a centralized service system was a common rule until the late 1980s and early 1990s, when the process of mass construction renovation was already underway in central Europe"[25]. So, for example, in Ljubljana, where the demand for housing is the highest in the country, approximately $50 \%$ of citizens live in micro-districts belonging to the socialistic type. The districts are suitable and sustainable for living; therefore, one can only talk about renovation. At this point, the interest is a public space, especially in comparison with the housing estates built after adapting the neo-liberal system in 1990. "Social ownership", denationalization, and privatization have caused errors in cadastral data, as well as uncertainty of property status, and have led to unsatisfactory maintenance and fragmentation of the public spaces. Mlinar assumes that "urban planning in the postmodern era must recognize something spontaneous and accidental, and actively provide for spontaneity and disorder", which confirms Fedchenko's findings [26]. It is tactical urbanism that can make it possible - inexpensive temporary interventions in the formed environment" [27]. Such way is interesting in that it opens opportunities for local planning, which is not hindered by the weak legislation. Instead of designing new spaces, there is a transformation of the current one accompanied by the vivid results. Community meetings, short-term projects, and other acts of "community association" can bridge the public and private sectors and provide opportunities for creativity. Tactical urbanism has proven to be effective in the post-socialist residential areas, as public space can be improved through slight interventions, regardless of the ownership structure, allocation of responsibilities, and / or lack of funding.

In the last five years, the scientific focus has been put into a definition of what the sotsgorod's cultural heritage is. There is a growing number of conferences (TU Darmstadt, 2019, Budapest University of Technology and Economics, 2015, 2017, 2019).

\section{CONCLUSION}

Criticism of architectural and planning rigidity in the "sotsgorod", theoretical and applied studies of real and potential development of the processes and qualities of residential construction have enabled approaching brand-new design technologies.

Considered changes in the "post-sotsgorod" morphology, social, political, and legislative structure of the territory, applicability, and influence of information technologies on the living environment development have modified architectural and urban planning activities. Regarding the technology of residential design, one can note a change in the process per se - an objective description of the design subject is replaced by analyzing the social forms of the action expressed in spatial creativity; under this case, the methods of adaptive planning have also been formed. In the design sphere, there is a tendency for an information-open policy in projecting and developing residential planning units - a timely coordination of residential objects development. The "information-open" micro-district aims a prompt response to the citizens and a "painless" design and construction of new facilities. An important step in the development of national urban planning is move from a monologue to interaction between the designers, business representatives, officials, and citizens. 
The expert view on that such a polylogue is not a misunderstanding of the obligation to provide the citizens with social guarantees is being actively backed up. The modern architectural and urban planning activities means the adherence to firm elements of the living environment and adaptive, tactical planning of flexible components that change under the influence of modernity.

\section{AUTHORS' CONTRIBUTIONS}

This paper is independently completed by Irina Kukina.

\section{REFERENCES}

[1] L.B. Kogan, Urbanization, globalization and urban policy (Urbanizatsiia, globalizatsiia i gorodskaia politika), in: City Government (Gorodskoe upravlenie), no. 12, 2007, pp. 212 [in Russian].

[2] I.V. Kukina, The image of a modern historical city: global trends in the renovation of regional values (Obraz sovremennogo istoricheskogo goroda: global'nye tendentsii renovatsii regional'nykh tsennostei), in: N.A. Konovalova (ed.), Modern architecture of the world (Sovremennaia arkhitektura mira), no. 2 (13), 2019, pp. 189-206 [in Russian].

[3] N.P. Krainyaya, Monotony and diversity in urban planning (Odnoobrazie i raznoobrazie $\mathrm{v}$ gradostroitel'stve), in: Academia. Architecture and Construction (Academia. Arhitectura i stroitel'stvo), no. 4, 2019, pp. 83-87 [in Russian].

[4] N.M. Trubnikova, The concept of the formation of the architectural and planning structure of the residential area of the city at the present stage (Kontseptsiia formirovaniia arkhitekturno-planirovochnoi struktury selitebnoi zony goroda na sovremennom etape), in: N.M. Trubnikova (ed.), Proceedings of the quality and efficiency of urban residential development (Kachestvo i effektivnost' zhiloi zastroiki gorodov), Moscow, 1984, pp. 12-18 [in Russian].

[5] A.A. Visokovsktii, G.Z. Kaganov, Urban environment: existence problems (Gorodskaia sreda: problemy sushchestvovaniia). Moscow, VNIITAG, 1990 [in Russian].
[6] K.V. Kiyanenko, Sociology of resilience versus architecture of segregation (Sotsiologiya ustoichivosti protiv arhitekturi segregatsii), in: Architecton. Proceedings of universities (Arhitekton. Izvestiya vuzov), no. 1 (49), 2015, pp. 3. URL: http://archvuz.ru/2015_1/3/ [in Russian].

[7] I.G. Fedchenko, Modern patterns of formation of residential planning units (Sovremennye zakonomernosti formoobrazovaniia zhilykh planirovochnykh edinits), in: Academia. Architecture and Construction (Academia. Arhitectura i stroitel'stvo), no. 4, 2019, pp. 7582 [in Russian].

[8] I.V. Kukina, Improvement of the naturalanthropogenic system of the residential areas of the 1960th years of construction. Dissertation of the Candidate of Architecture (Sovershenstvovanie prirodnoantropogennogo komplekca zhiloi zastroiki 1960-h godov stroitel'stva. Dissertatsiia kandidata arkhitektury). Moscow, 1992 [in Russian].

[9] A.G. Bolshakov, Method for assessing the geometry of an urban landscape by the conditions of its ability to live (Metod otsenki geometrii gorodskogo landshaphta po usloviyam ego zhizneprigodnosti), in: Proceedings of Irkutsk State Technical University (Vestnik Irkutskogo technicheskogo universiteta), no. 5 (45), 2010, pp. 86-88 [in Russian].

[10] V.A. Nefedov, Landscaping and environmental sustainability (Landshaftnii disain i ustoichivost sredi). Sankt-Peterburg, Poligraphst, 2002 [in Russian].

[11] N.A. Unagaeva, Ecological-guided design of the inhabited lanscape (Ecologoorientirovannoe proektirovanie landhaphta), in: Proceedings of Orienburg State University (Vestnik Orienburgskogo gosudarstvennogo universiteta), no. 5 (166), 2014, pp. 149-154 [in Russian].

[12] L.V. Anisimova, Urban landscape: socioecological aspects of design (Gorodskoi landshapht: ekologicheskie aspect proektirovaniya). Vologa, VoGTY, 2002 [in Russian]. 
[13] B. Engel, Public space in the blue cities of Russia, in: Progress in Planning, vol. 66, issue 3, 2006, pp. 147-239.

[14] I. Szelenyi, Cities under socialism - and after, in: G.D. Andrusz, M. Harloe, I. Szelenyi (eds.), Cities After Socialism: Urban and Regional Change and Conflict in PostSocialist Societies. Oxford, Blackwell, 1996, pp. 286-317.

[15] K. Stanilov (ed.), The post-socialist city: Urban form and Space Transformations in Central and Easten Europe after Socialism. Dordrecht, Springer, 2007.

[16] V. Hoxha, K. Dimitrovska-Andrews, A. Temeljotov Salaj, Cultural factors affecting urban planners' intentions to regulate public space in Prishtina, Kosovo, in: Urbani Izziv, no. 25 (2), 2014, pp. 76-89.

[17] K.V. Kiyanenko, Sociology of resilience versus architecture of segregation (Sotsiologiya ustoichivosti protiv arhitekturi segregatsii), in: Architecton. Proceedings of universities (Arhitekton. Izvestiya vuzov), no. 1 (49), 2015, pp. 3. URL: http://archvuz.ru/2015_1/3/ [in Russian].

[18] G.A. Ptichnikova, A.V. Antufeev, New morphotypes of architectural space of modern (Novie morphotipi architecturnogo prostranstva sovremennikh gorodov), in: Urban Sociology (Sotsiologiya goroda), no. 2, 2014, pp. 5-19 [in Russian].

[19] E.V. Eshchina, Socio-democratic methods of participation in the city-regulating activity of an architect: on the example of Penza. Dissertation of the candidate of Architecture (Sotsial'no-demokraticheskie metody souchastiia v gradoreguliruiushchei deiatel'nosti arkhitektora: na primere g. Penzyiu Dissertatsiia kandidata arkhitektury). Nizhy Novgorod, 2004 [in Russian].

[20] T.V. Filanova, Formation of local socioterritorial formations in the largest established city: on the example of Samara. Dissertation of the Candidate of Architecture (Formirovanie lokal'nykh sotsial'noterritorial'nykh obrazovanii $\mathrm{v}$ krupneishem slozhivshemsia gorode: na primere g. Samary. Dissertatsiia kandidata arkhitektury). Samara, 2008 [in Russian].
[21] I.G. Fedchenko, Formation of residential planning units in the middle XX - early XXI century (Formirovanie zhilykh planirovochnykh edinits $\mathrm{v}$ seredine XX nachale XXI veka). Krasnoyarsk, 2007 [in Russian].

[22] N.P. Krainyaya, Monotony and diversity in urban planning (Odnoobrazie i raznoobrazie $\mathrm{v}$ gradostroitel'stve), in: Academia. Architecture and Construction (Academia. Arhitectura i stroitel'stvo), no. 4, 2019, pp. 83-87 [in Russian].

[23] K.V. Kiyanenko, Sociology of resilience versus architecture of segregation (Sotsiologiya ustoichivosti protiv arhitekturi segregatsii), in: Architecton. Proceedings of universities (Arhitekton. Izvestiya vuzov), no. 1 (49), 2015, pp. 3. URL: http://archvuz.ru/2015_1/3/ [in Russian].

[24] I.V. Kukina, The image of a modern historical city: global trends in the renovation of regional values (Obraz sovremennogo istoricheskogo goroda: global'nye tendentsii renovatsii regional'nykh tsennostei), in: N.A. Konovalova (ed.), Modern architecture of the world (Sovremennaia arkhitektura mira), no. 2 (13), 2019, pp. 189-206 [in Russian].

[25] V. Hoxha, K. Dimitrovska-Andrews, A. Temeljotov Salaj, Cultural factors affecting urban planners' intentions to regulate public space in Prishtina, Kosovo, in: Urbani Izziv, no. 25 (2), 2014, pp. 76-89.

[26] Z. Mlinar, About the spatial-temporal (disorder) at the "end of great stories" (O prostorsko - casovnem (ne-)redu ob "koncu velikih zgodb"), in: I. Cerpes (Eds.) On urbanism: What's going on with the modern city? (O urbanizmu: Kaj se dogaja s sodobnim mestom?). Ljuibljiana, 2007, pp. 341-369 [in Slovenian].

[27] L. Pfeifer, The Planner's Guide to Tactical Urbanism. Montreal, Canada, 2013. 